Int. J. Dev. Biol. 52: 323-332 (2008)

doi: $10.1387 / \mathrm{ijdb} .072490 \mathrm{gh}$

\title{
Loss of Sox9 function results in defective chondrocyte differentiation of mouse embryonic stem cells in vitro
}

\author{
GUNNAR HARGUS ${ }^{1, \#, ~ R A L F ~ K I S T ~}{ }^{2,3, \# \#, ~ J A N ~ K R A M E R ~}{ }^{1,4}$, DANIELA GERSTEL ${ }^{1}$, ANGELA NEITZ¹, \\ GERD SCHERER ${ }^{2}$ and JÜRGEN ROHWEDEL*,1

\begin{abstract}
${ }^{1}$ Dept. of Medical Molecular Biology, University of Lübeck, Lübeck, 2Institute of Human Genetics and Anthropology, University of Freiburg, Freiburg, ${ }^{3}$ Institute of Mammalian Genetics, GSF-National Research Center for Environment and Health, Neuherberg and ${ }^{4}$ Medical Clinic I, University of Lübeck, Lübeck, Germany.
\end{abstract}

\begin{abstract}
The transcription factor Sox9 plays an important role during chondrogenesis. After early conditional inactivation of Sox9 in mesenchymal limb bud cells of mice, mesenchymal condensations as well as cartilage and bone are completely absent in the developing limbs. We analyzed chondrogenic differentiation of Sox $9^{-/-}$mouse embryonic stem cells in vitro, using two clones with different targeted mutations. We found that the development of mature and hypertrophic chondrocytes is completely inhibited in the absence of Sox9 confirming that Sox9 is required for the formation of cartilage. In contrast, Sox $9^{+/-}$mouse embryonic stem cells showed continous but reduced differentiation into mature chondrocytes. Interestingly, the formation of early chondrogenic condensations expressing characteristic marker genes such as scleraxis, Sox 5 and Sox6 was not inhibited in the absence of Sox9 in vitro. Thus, we propose that the earliest step of chondrogenesis could be regulated by a non cell-autonomous function of Sox9.
\end{abstract}

KEY WORDS: chondrogenesis, in vitro differentiation, mesenchymal condensations, Sox9

\section{Introduction}

Sox9 is a member of the SOX (Sry-related high mobility group box) family of transcription factors that share a common 79 amino acid DNA binding motif, known as the high-mobility group (HMG) domain, with the mammalian testis-determining factor SRY (Wegner, 1999; Bowles et al., 2000). Evidence exists that Sox9 plays an important role during cartilage development (de Crombrugghe et al., 2001). During mouse embryogenesis, Sox9 is expressed in all regions of cartilage formation including the sclerotomal parts of the somites that give rise to the axial skleleton, the cartilaginous elements of the limb buds which are formed by the lateral plate mesoderm, and in neural crest-derived mesenchymal cells of the craniofacial region (Zhao et al., 1997; $\mathrm{Ng}$ et al., 1997). In these structures, mesenchymal cells which differentiate into chondroprogenitor cells and form condensations have been shown to express Sox9 (Wright et al., 1995) as well as the cell adhesion molecule $\mathrm{N}$-cadherin (Oberlender and Tuan, 1994), the basic-helix-loop-helix transcription factor scleraxis (Cserjesi et al., 1995) and the transcription factors Sox5 and Sox6 (Lefebvre et al., 1998). These cells continue to express Sox9during further differentiation, which is characterized by expression and deposition of cartilage-specific matrix components such as collagen type II and aggrecan. Sox9 is completely downregulated when chondrocytes acquire a hypertrophic shape and start to express Col10a1 (Zhao et al., 1997). Sox9 binds to target sites in promoters or enhancers of cartilage-specific genes such as Col2a1 (Lefebvre et al., 1997; Zhou et al., 1998), Col11a2 (Bridgewater et al., 1998), and aggrecan (Sekiya et al., 2000), and has been shown to activate the expression of these genes in vitro. Furthermore, Col2a 1 has been identified as a direct target gene of Sox9 in vivo (Bell et al., 1997; Zhou et al., 1998).

Heterozygous mutations in the human SOX9gene cause the skeletal malformation syndrome campomelic dysplasia (CD) and associated XY sex reversal (Foster et al., 1994; Wagner et al., 1994), which establishes SOX9 as an essential factor for

Abbreviations used in this paper: EB, embryoid body; ES, embryonic stem (cell); HMG, high mobility group; HR, homologous recombination; PNA, peanut agglutinin; SOX, Sry-related high mobility group box.

\footnotetext{
*Address correspondence to: Dr. Jürgen Rohwedel. Dept. of Medical Molecularbiology, Medical University of Lübeck, Ratzeburger Allee 160, 23538 Lübeck, Germany. Tel: +49-451-500-4095. Fax:+49-451-500-3637. e-mail: rohwedel@molbio.uni-luebeck.de - web address: www.molbio.uni-luebeck.de/rohwedel.htm

Present addresses: \# Center for Molecular Neurobiology, University of Hamburg, D-20251 Hamburg, Germany. \#\# The Institute of Human Genetics, The International Centre for Life, Central Parkway, Newcastle upon Tyne, NE1 3BZ, United Kingdom.
} 
A

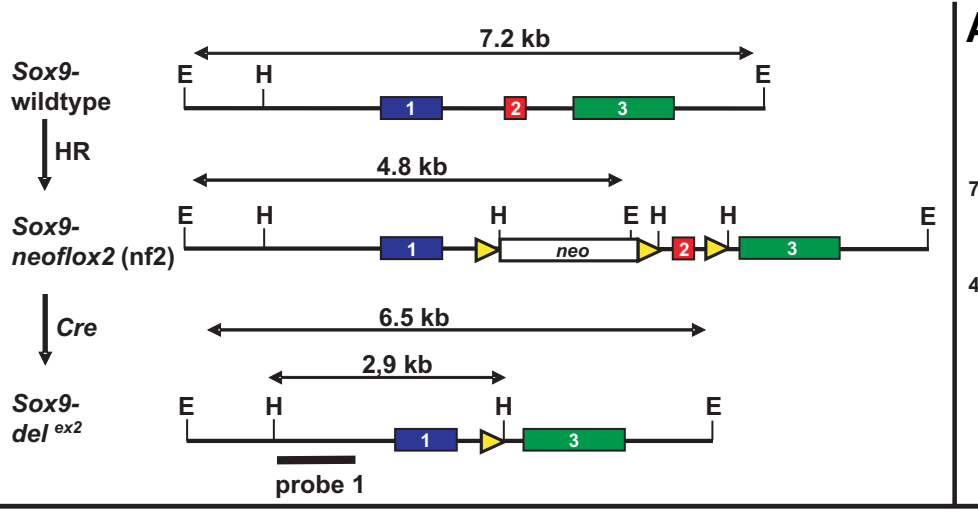

B

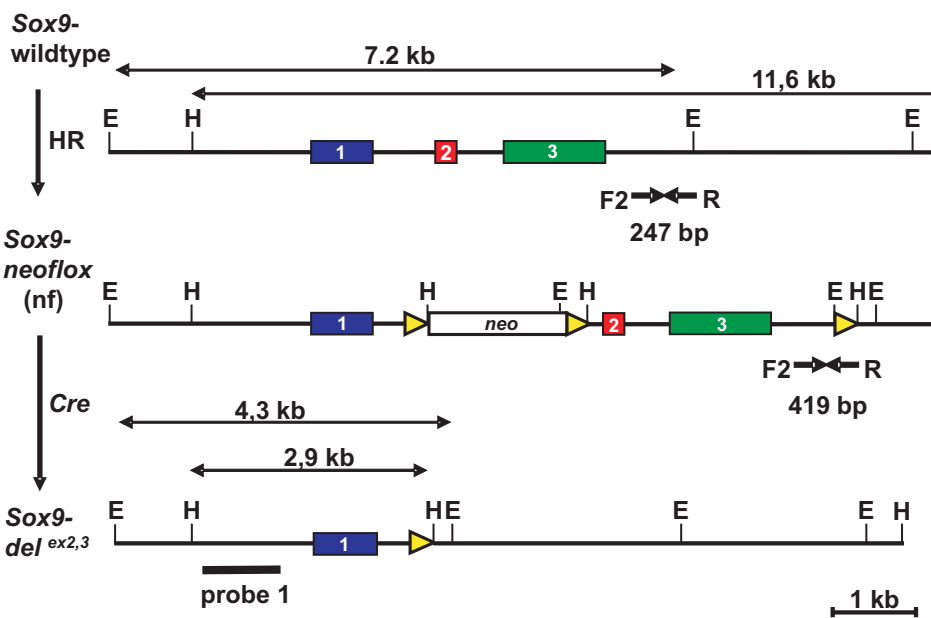

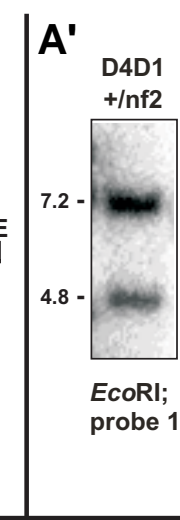

probe 1

Fig. 1. Sox9 gene targeting strategies and inactivation by Cre-mediated recombination in ES cells. The Sox9-neoflox2 (A) and Sox9-neoflox (B) alleles, carrying loxP-flanked MC1-neo-pA cassettes (neo, open boxes) inserted into intron 1 and a third loxP site inserted into intron 2 or into the 3' untranslated region, respectively, were generated by homologous recombination (HR) in ES cells. The loxP-flanked neo cassettes and either, Sox9 exon 2 (A) or exon 2 and 3 (B) were removed by transient expression of Cre recombinase in vitro resulting in the Sox9-delex2 and Sox9-delex2,3 alleles, respectively. Colored boxes, Sox9 exons 1-3; triangles, loxP sites; E, EcoRl; $H$, HindIII. Expected restriction fragment sizes detected by the hybridisation probe $1(\mathbf{A}, \mathbf{B})$, or the lengths of $P C R$ fragments amplified with primers $F 2$ and $R(\mathbf{B})$ are indicated. (A') Southern blot analysis of the heterozygous Sox9-neoflox2 clone D4D1 shows the wildtype 7,2 kb EcoR1 and the floxed 4,8 kb Eco RI band. (B') PCR analysis of wildtype and Sox9neoflox ES cell clones demonstrates replacement of the wildtype allele with the mutant allele in a homozygous Sox9-neoflox clone. (C) Southern Blot analysis of wildtype (E14.1), heterozygous D4D6 and homozygous Sox9-delex2 (D4D12-C4) and Sox9-delex2,3 (2A5-40) ES cell clones. Homologous recombination and Cre-mediated deletion was confirmed using probe 1 showing a 6,5 kb EcoR1 and a 2,9 kb Hind/Il fragment in homozygous Sox9delex2 clone D4D12-C4 and a 4,3 kb EcoRl and a 2,9 kb Hindlll fragment in homozygous Sox9-delex2,3 clone 2A5-40.

skeletogenesis and for testis determination. Defects are due to haploinsufficiency, indicating that a reduced dosage of SOX9 causes the developmental abnormalities. Characteristic features in CD patients are defective skeletal structures such as bowing and angulation of the tibiae and femora, hypoplastic scapulae and pelvic bones, undermineralized vertebrae and craniofacial malformations. Possibly due to defective tracheobronchial cartilages and narrow upper airways, most patients die in the neonatal period from respiratory distress (Houston et al., 1983; Mansour et al., 1995). Heterozygous Sox9-mutant mice generated by gene targeting phenocopy many of the features seen in CD patients, and also show typical abnormalities in cartilage primordia and premature skeletal mineralization (Bi et al., 2001; Kist et al., 2002).

In mouse chimeras, Sox9-/- cells were excluded from cartilage primordia and mature cartilage tissue throughout embryonic development (Bi et al., 1999). Moreover, Sox9-/ teratomas did not form any cartilage tissues (Bi et al., 1999) and both, in chimeras and teratomas, Sox9-/- cells failed to produce type II collagen. Furthermore, cartilage and bone was completely absent in the limbs of mice after conditional inactivation of the Sox9gene in early mesenchymal limb bud cells, and severe chondrodysplasia was described when Sox9 was conditionally inactivated after mesenchymal condensations had formed (Akiyama et al., 2002).

As an alternative to homozygous Sox 9 knockout mice, we analyzed differentiation of Sox9-/- embryonic stem (ES) cells in vitro to elucidate which steps of chondrocyte differentiation are affected by loss of Sox9 function. Using the model system of ES cell differentiation via embryoid bodies (EBs), we have recently demonstrated that the process of chondrocyte differentiation is closely recapitulated in vitro, finally resulting in hypertrophic and calcifying cells (Kramer et al., 2000; Hegert et al., 2002; Kramer 
et al., 2005). Here, we demonstrate that murine Sox9/- ES cells differentiate in vitro into pre-cartilage condensations which express early chondrocytic marker molecules such as the transcription factors Sox5, Sox6 and scleraxis and also bind peanutagglutinin. However, Sox9-/- cells fail to develop further and are not able to form cartilage nodules and hypertrophic chondrocytes in vitro.

\section{Results}

\section{Generation of Sox9+/- and Sox9-/- ES cells}

By homologous recombination with a Sox 9 targeting vector, several correctly targeted ES cell clones were identified carrying the modified allele Sox9-neoflox2 (Kist et al., unpublished). One of the Sox9-neoflox2 clones, D4 was used to generate Sox9+/- ES cells by transient in vitro expression of Cre recombinase. Upon complete recombination the loxPflanked neo cassettes are removed together with exon 2, resulting in the deleted allele Sox9-depex2 (Fig. 1A). Several partially or completely recombined ES cell clones were identified by Southern blot analysis (data not shown). Three particular clones, D4D1, D4D6 and D4D12, were generated from the Sox9neoflox2cells and characterised in detail (Fig. $1 \mathrm{~A}, \mathrm{C})$. Clone D4D1 is identical to the parental clone D4 in which no recombination by Cre recombinase had occurred. The $4.8 \mathrm{~kb}$ EcoRl fragment in clone D4D1 indicates the presence of the neo cassette in the targeted allele (Fig. 1A'), while in clone D4D6, the 6.5 $\mathrm{kb} E \mathrm{CORI}$ and the 2,9kb Hindll fragment indicate the deleted allele (Fig. 1C). Surprisingly, in clone D4D12, the Sox9 wildtype allele on the non-targeted chromosome had been replaced by the deleted Sox9allele, resulting in a Sox9-/-genotype, lacking exon 2 . This clone was subcloned because a very weak wildtype band was detectable after prolonged exposure possibly due to contaminating wildtype cells (data not shown) and the resulting subclones D4D12-C4 and

Fig. 2. Loss of functional Sox9 expression in Sox9/embryoid bodies. (A) RT-PCR analysis of RNA isolated from wildtype (wt), heterozygous (Sox9+/-) and homozygous (Sox9-/-) embryoid bodies generated from ES cell clones D4D6, D4D12-C4 or 2A5-40. Oligonucleotide primers specifically binding in exon 1 and 3 of the Sox 9 gene could not amplify any wildtype fragment (723 bp) in both homozygous mutant ES cell clones. Instead, a 469 bp fragment was detected for the Sox9-del ${ }^{\mathrm{e} 2}$ clone D4D12-C4, while no other fragment was detected for the Sox9-de ex2,3 clone 2A5-40. (B) DNA sequencing of the $469 \mathrm{bp} R T-P C R$ product revealed splicing of exon 1 to exon 3 resulting in a frameshift mutation, caused by the lack of the 254 bp-long exon 2. This nucleotide sequence predicts an aberrant peptide which would code only for the first half of the HMG box (blue; $D$ HMG-box; 42 amino acids) followed by an altered amino acid sequence and a stop codon at position 166. (C) During in vitro differentiation, Sox9 protein was detected by immunostaining in wildtype EB outgrowths $(a, b)$ but not in Sox9-/- (D4D12-C4 and 2A5-40) EB outgrowths (c, d). Representative areas are shown (wildtype and clone D4D12-C4). $D I C=$ differential interference contrast. Scale bar, $100 \mu \mathrm{m}$.

B
D4D12-D6 were verified by Southern Blotting showing only the EcoRl $6,5 \mathrm{~kb}$ and the $2,9 \mathrm{~kb}$ Hindll fragment, respectively (Fig.1C). These subclones were used for the differentiation experiments.

In addition, an ES cell clone with a different modified allele, Sox9-neoflox (Kist et al., 2002), was used to generate a Sox9/clone lacking both, exon 2 and 3 (Fig. 1B). From ES cell clone $2 \mathrm{~A}$, carrying the Sox9-neoflox allele (Kist et al., 2002) in a heterozygous configuration, clone $2 \mathrm{~A} 5$ was selected after cultivation with high concentrations of G418. PCR analysis showed that this clone carried the Sox9-neofloxallele in a homozygous configuration (Fig. 1B'). Replacement of the wildtype allele on the non-targeted chromosome by the mutant allele, is known to occur spontaneously and has been used before to generate homozygous ES cell clones (Mortensen et al., 1992; Lefebvre et al., 2001). After Cre expression, the subclone 2A5-40 was
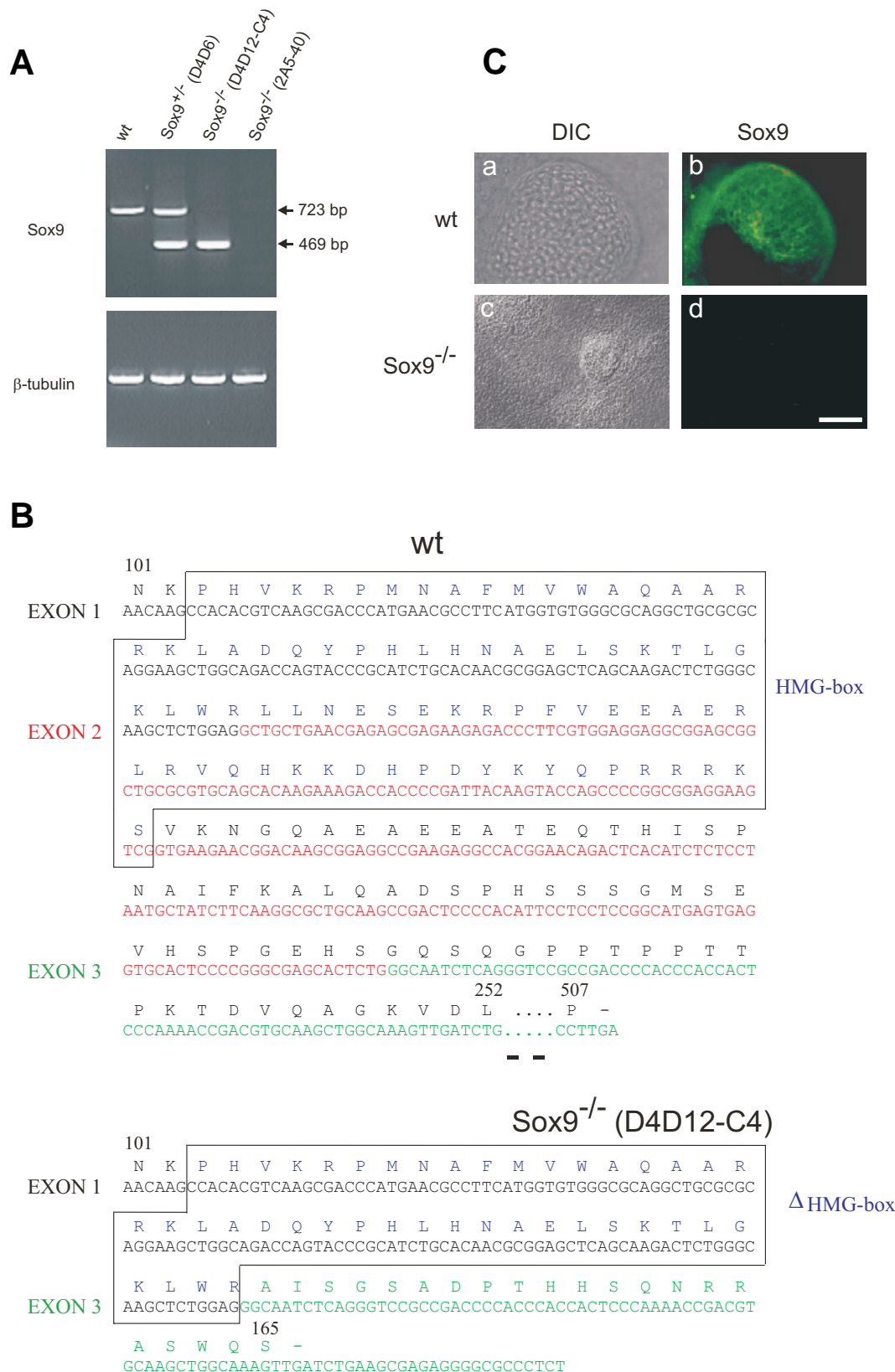

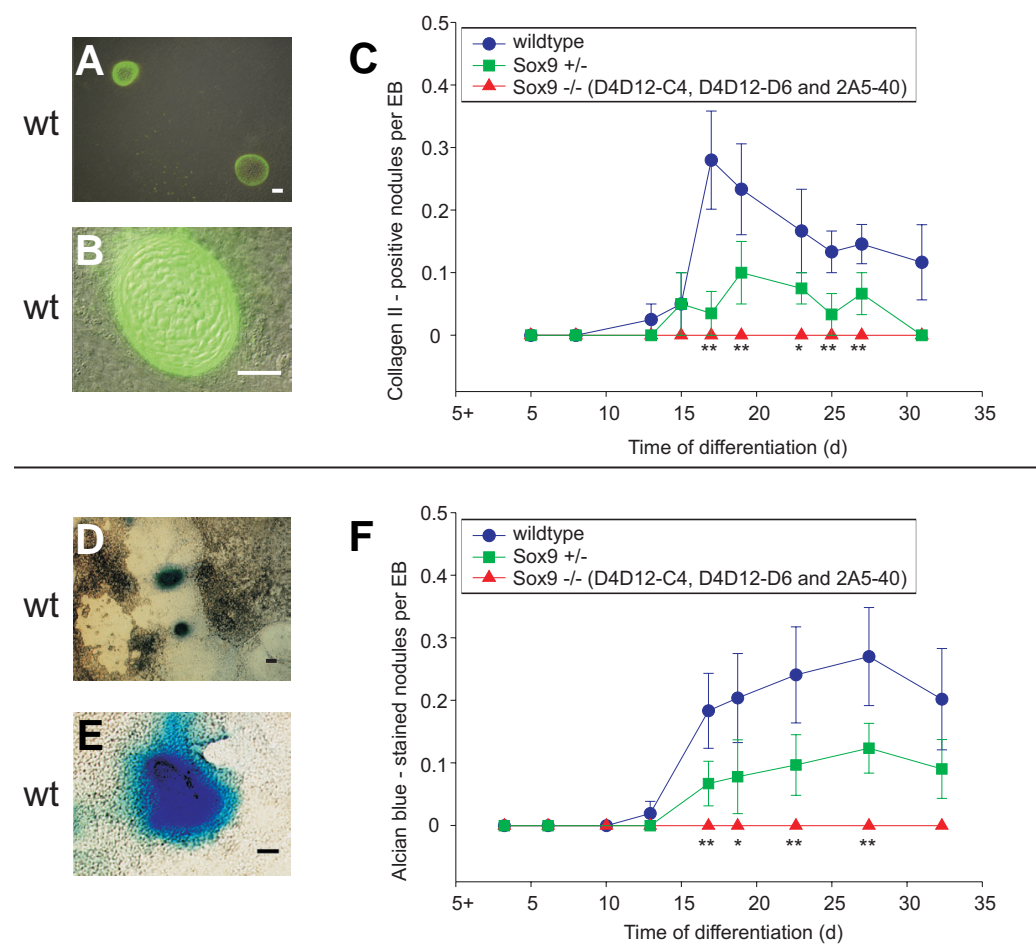
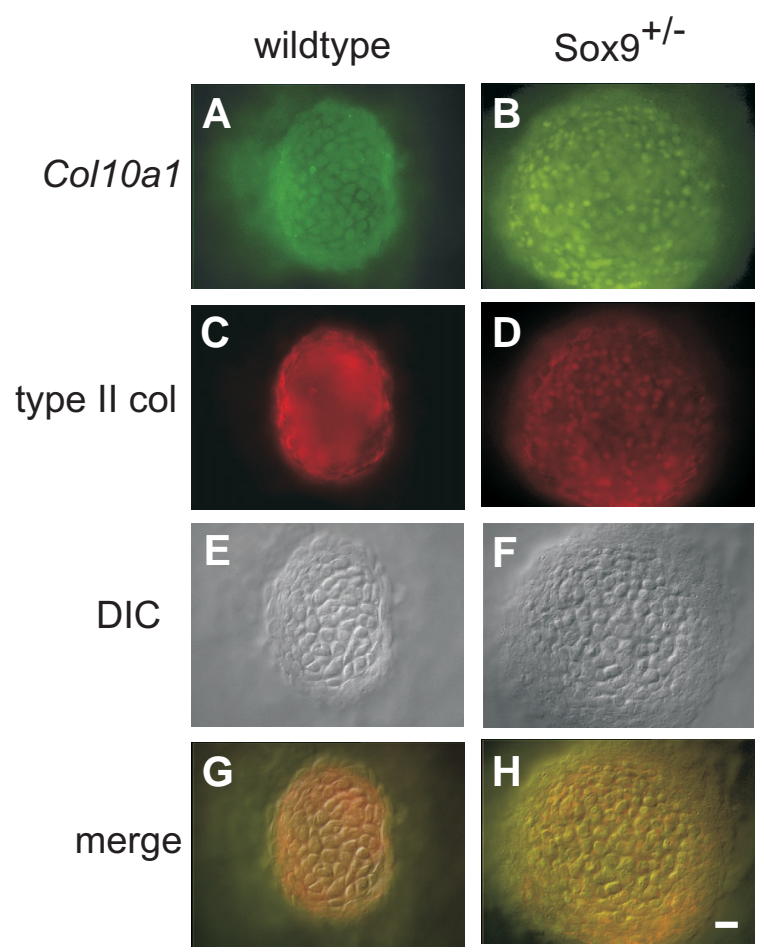

Fig. 3 (Left). Sox9-/-ES cells are not able to differentiate into mature chondrocytes forming cartilage nodules. The number of cartilage nodules (A,B,D,E) was determined in embryoid body (EB) outgrowths of wildtype (wt), Sox9+/-(D4D6) and Sox9-/- (D4D12-C4, D4D12-D6 and 2A5-40) ES cells after immunostaining for type // collagen (A-C) and after Alcian blue staining (D-F). Whereas in wildtype EBs, the first nodules were found 13 days after plating $(5+13 d)$, and two days later in Sox $9+/-E B s(5+15 d)$, no such structures could be detected in Sox9-/-EBs (C,F). In Sox9+/- EBs, the number of nodules appeared to be reduced but the differences were not statistically significant. Mean values \pm SEM from at least three independent experiments are shown. Because we found less than 1 nodule per EB in the wildtype EBs we analyzed approximately 200 EBs per day. Significant differences between wildtype and Sox9-/- EBs: * $p \leq 0.05 ;{ }^{*}: p \leq 0.01$. Scale bars, $100 \mu \mathrm{m}$.

Fig. 4 (Right). Wildtype and Sox9+/- embryoid bodies (EBs) form nodules consisting of hypertrophic chondrocytes. Wildtype (A,C,E,G) and Sox9+/-(B,D,F,H) ES cells differentiated into Col10a1-(A,B) and type /l collagen (C,D)-positive cells. These cells were embedded in abundant extracellular matrix and formed cartilaginous nodules (E,F). Merging of the pictures demonstrates that type // collagen is evenly distributed between the Col10a1expressing cells derived from wildtype and Sox9+/-ES cells $\mathbf{( G , H ) . ~ S o x 9 - / - ~ E S ~ c e l l s ~ d o ~ n o t ~ f o r m ~ c a r t i l a g e ~ n o d u l e s . ~ E B s ~ w e r e ~ a n a l y z e d ~ a t ~} 5+28$ d by in situ hybridization for Col10a1 mRNA combined with immunostaining for type // collagen. DIC, differential interference contrast. Scale bar, $100 \mu$ m.

selected which only carried the Sox9-depx2,3 alleles as verified by Southern Blotting showing 4,3 kb EcoRI and 2,9 kb Hindll fragments, respectively (Fig. 1C).

To investigate the Sox9 transcripts generated from the Sox9-de ${ }^{e \times 2}$ allele, we performed RT-PCR with RNA isolated from ES cell clones D4D6 and D4D12-C4 and sequencespecific primers located in exon 1 and exon 3 . We found that the fragment amplified from the transcripts of the deleted allele (469 bp) was 254 bp shorter than the wildtype fragment (723 bp) and no Sox9 wildtype transcripts could be detected in clone D4D12-C4 (Fig. 2A). DNA sequencing of the mutant $469 \mathrm{bp}$ fragment showed that exon 2 was completely deleted and exon 1 was spliced to exon 3 resulting in a frameshift mutation. If a protein was to be translated from the mutant transcript of the Sox9-depx2 allele, it would consist of 165 instead of 509 amino acids, carrying a truncated HMG domain followed by 21 out-offrame amino acids encoded by exon 3 (Fig. 2B). RT-PCR with RNA isolated from ES cell clone 2A5-40 carrying the Sox9$d_{e}{ }^{\times 2,3}$ allele did not result in any amplification product (Fig. 2A). By immunostaining we were not able to detect any Sox9 protein in the knock-out clones D4D12-C4 (Fig. 2C) and 2A5-40 (data not shown) during differentiation.

\section{Sox9-/- cells are unable to develop into mature chondrocytes in vitro}

ES cells differentiate in vitro into highly organized cartilage nodules (Kramer et al., 2000). To test for the chondrogenic in vitro differentiation capacity in the absence of Sox9, wildtype, Sox9+/and Sox9-/- ES cells were analyzed by counting type II collagenpositive cartilage nodules (Fig. $3 \mathrm{~A}, \mathrm{~B}$ ) in EB outgrowths. We found that cells of the Sox9/- clones D4D12-C4 and D4D12-D6 and of the different Sox9-/- clone 2A5-40 did not differentiate into these highly organized cartilage structures during EB cultivation up to 5+31 d (Fig. 3C). In contrast, in Sox9+/- EB outgrowths, nodules appeared but the number was reduced in comparison to the wildtype control (Fig. 3C). The first nodules were detected in wildtype EBs at 5+13 d, their number increased up to $5+17 \mathrm{~d}$ and decreased thereafter. Similarly, in Sox9+/- EB outgrowths, the first nodules formed at $5+15 \mathrm{~d}$, the maximum number was detected at 5+19 d and decreased later. The mean values for the number of type II collagen-positive nodules in Sox9+/- EB outgrowths never reached the wildtype levels, although the differ- 
ences were not statistically significant. These results were confirmed by Alcian blue staining, which showed that deep blue stained nodules (Fig. 3D,E) were completely absent in Sox9-/- EB outgrowths up to $5+33 \mathrm{~d}$, and that their number was reduced in Sox9+/- EBs (Fig. 3F). Alcian blue specifically stains acidic proteoglycans found in the extracellular matrix of cartilage tissue. The maximum number of Alcian blue-stained nodules was observed at later stages as compared to type II collagen-positive nodules, in both wildtype and Sox9+/- EBs. This is probably due to the fact that the Alcian blue-stained proteoglycans and type II collagen are subsequently expressed during terminal chondrogenic differentiation in EBs. In summary, these data demonstrate that Sox9 is required for the formation of highly organized cartilage nodules in vitro.

To characterize the terminal stage of chondrocyte differentiation in more detail, the expression of Col10a1 was analyzed, a marker for hypertrophic chondrocytes appearing at the latest differentiation steps during endochondral differentiation in vivo. In situ hybridization for Col10a1 mRNA (Fig. 4 A,B) combined with immunostaining for type Il collagen (Fig. 4 C,D) demonstrated that hypertrophic chondrocytes co-expressing Col10a1 and type II collagen were present in wildtype and Sox9+/- EBs but not in Sox9-/- EBs (not shown). These results show that chondrogenic cells in Sox9+/- ES cell-derived nodules become hypertrophic. Hypertrophic cells of wildtype and Sox9+/- EBs did not show any obvious differences regarding their morphology or expression and distribution of type II collagen (Fig. 4 C-F). However, in situ hybridization showed that expression of Col10a1 was always stronger in Sox9+/- EBs and the number of Col10a1 expressing cells seemed to be increased compared to the wildtype (Fig. 4 $A, B)$.

\section{Sox9-/- ES cells are able to form pre-cartilage condensations in vitro}

To see whether already early steps of chondrogenic differentiation were affected after complete loss of Sox 9 function in vitro, we tested the EBs for the presence of pre-cartilage condensations. To this end we analyzed wildtype and Sox9/- (clones D4D12-C4, and 2A5-40) EB outgrowths for expression of Sox5 (Fig. $5 \mathrm{~A}-\mathrm{C}$ ) and Sox6(Fig. $5 \mathrm{~J}-\mathrm{L}$ ) and found that both markers are coexpressed with type II collagen in pre-cartilage condensations of wildtype and Sox9-/- EB outgrowths (Fig. 5). Control slides hybridized with the respective sense probes and the secondary antibody alone were negative (data not shown). Condensations in both, wildtype and Sox9-/- (D4D12-C4, and 2A5-40) EB outgrowths, displayed intensive binding of PNA (Fig. $5 \mathrm{~S}-\mathrm{U}$ ), demonstrating that pre-cartilage condensations are formed in the absence of Sox9. Identical results were obtained for the Sox9-/clone D4D12-D6 (data not shown).

To analyze condensation formation on a quantitative level, we analyzed wildtype, Sox9+/- and Sox9-/- (D4D12-C4) EBs for the formation of $\mathrm{N}$-cadherin- and scleraxis-positive cell condensations. We found scleraxis- (Fig. 6 A-C) and N-cadherin- (Fig. 6 D$\mathrm{F})$ positive cell condensations in EB outgrowths of wildtype, Sox9+/- and Sox9-/- ES cells during cultivation. There were no obvious morphological differences between these pre-cartilage structures among the three genotypes and we did not find any significant quantitative differences in the number of scleraxispositive condensations between wildtype, Sox9+/- and Sox9/-

EBs (Fig. $6 \mathrm{~J}$ ). The same results were obtained when we studied expression of scleraxis and N-CAM, which are also characteristically co-expressed by cells forming pre-cartilage condensations (data not shown).

Together, these results indicate that Sox9 inactivation does

wt
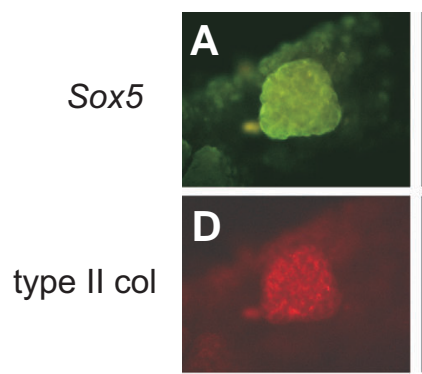

DIC
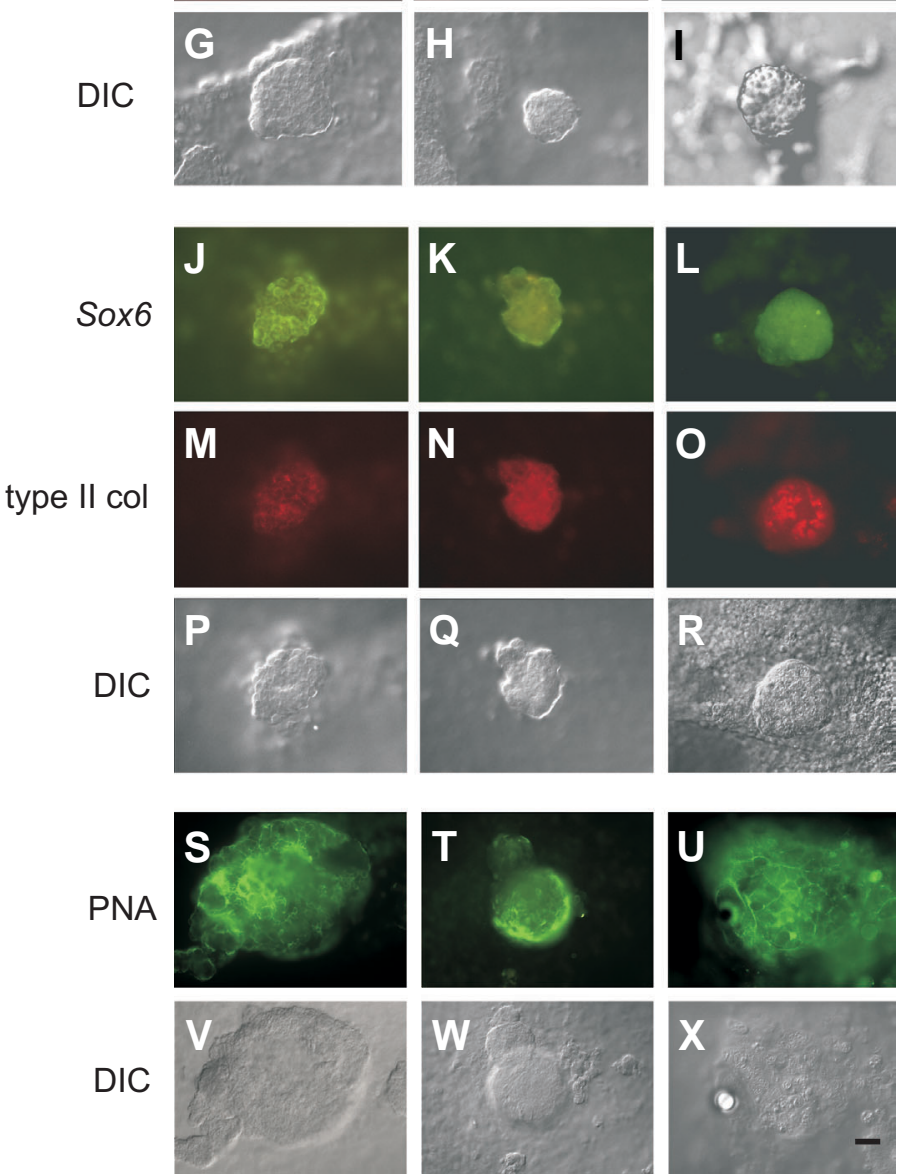

Fig. 5. Pre-cartilage condensations show expression of Sox5 and Sox6 and bind peanut agglutinin (PNA) in the absence of Sox9. In situ hybridization for Sox5 (A-C) and Sox6 mRNA (J-L) combined with immunostaining for type // collagen (D-F, M-O) and DIC microscopy (GI, P-R) showed that mesenchymal cells in wildtype ( $w t ; A, D, G, J, M, P)$ and Sox9-- EBs derived from the two different Sox9-/-ES cell clones D4D12-

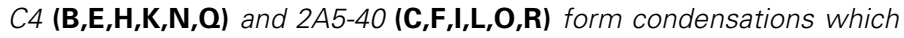
express Sox5 and Sox6. Such condensations also bind fluoresceinlabeled PNA in wildtype (S,V) and Sox9-/- EBs derived from clones $D 4 D 12-C 4(\mathbf{T}, \mathbf{W})$ and $2 A 5-40(\mathbf{U}, \mathbf{X})$. Representative areas from $E B$ outgrowths are shown. Scale bar, $100 \mu \mathrm{m}$. 
not affect the formation of early pre-cartilage condensations during $\mathrm{ES}$ cell differentiation in vitro.

\section{Col2a1 expression is downregulated but not completely abolished during in vitro ES cell differentiation in the ab- sence of Sox 9}

Because Sox9 is an activator of the Col2a1 gene both in vivo and in vitro, we performed conventional and quantitative RT-PCR of Sox9-deficient EBs. Using primer which amplify two splice variants of Col2a 1, a juvenile and an adult form (Metsäranta et al., 1991), we found that both were expressed in Sox9/- EBs of clones D4D12-C4 and 2A5-40 (Fig. 7A). This was confirmed by immunostaining of EB cultures for collagen type II. Both, in wildtype and Sox9-/- EBs, type II collagen-fibers could be detected at late differentiation stages, scattered throughout the EB outgrowths (Fig. 7 C,D). These fibers were also found in Sox9+/EB outgrowths (not shown). To determine the level of Col2a1 expression in wildtype and Sox9-/- cells, EBs of clone 2A5-40 and D4D12-C4 were analyzed by real-time RT-PCR for expression of Col2a1 using primers which do not discriminate between both splice variants. Col2a 1 was still expressed but clearly downregu-

scleraxis
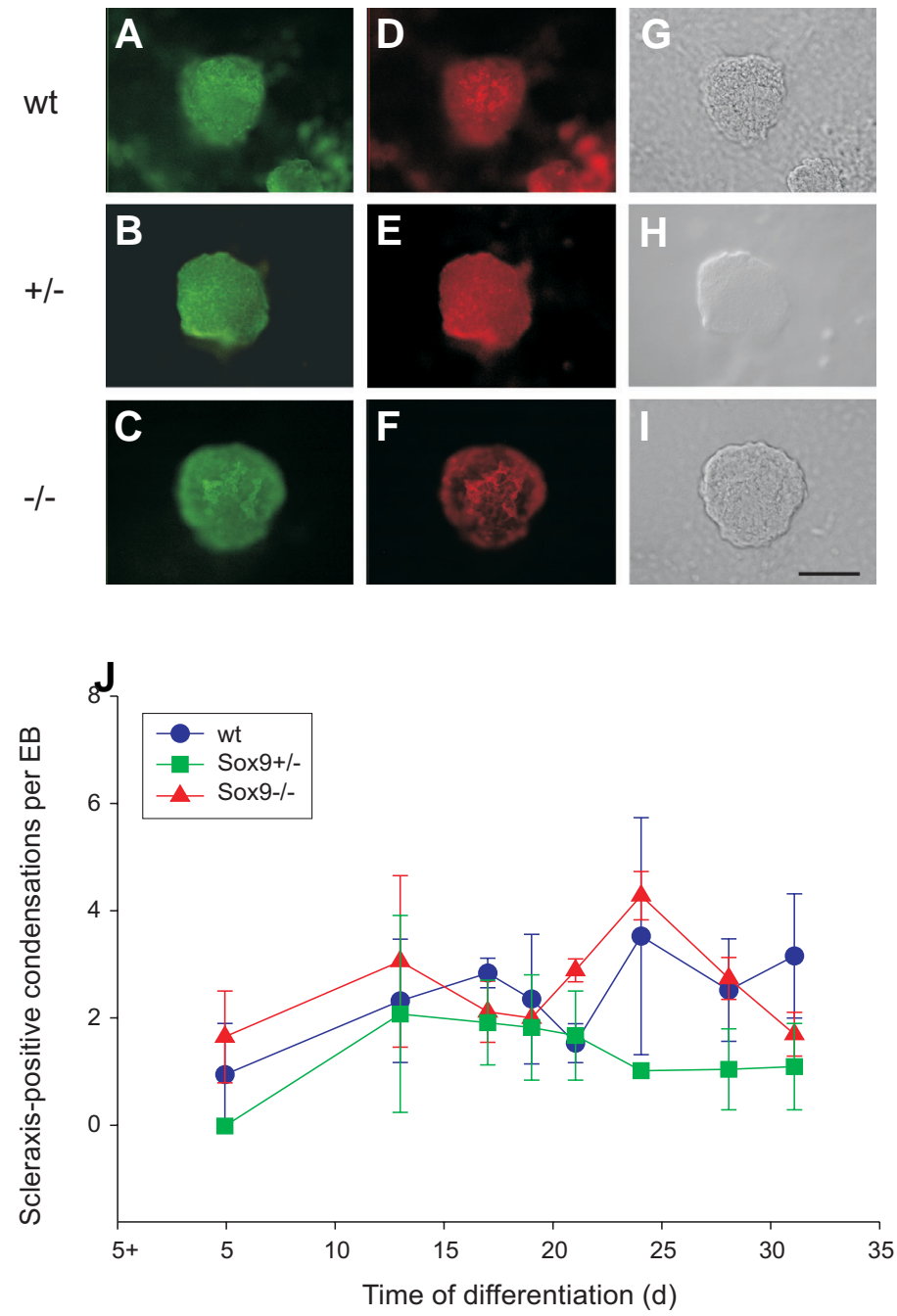

lated in the absence of Sox9 (Fig. 7 B). Thus, Sox9 seems to be required for an upregulated expression of Col2a1 but other factors may compensate for a basal expression at least in vitro.

\section{Discussion}

\section{Sox9 is required for ES cell differentiation into cartilage nodules in vitro}

Our results demonstrate that in vitro differentiation of Sox9-/ES cells into chondrocytes is disrupted at a stage characterised by the appearance of typical round-shaped chondrocytes organized in distinct nodules and expressing a high level of type II collagen. Sox9-/- cells fail to form these cartilage nodules. In line with this, it has been demonstrated that Sox9-deficient cells could not differentiate into mature chondrocytes in mouse Sox9/chimeras and teratomas (Bi et al., 1999). Furthermore, conditional null mutant mice lacking Sox9 in mesenchymal cells of limb buds were not able to form cartilage and bone in limbs (Akiyama etal., 2002). Since we found in previous studies that the formation of cartilage nodules in differentiating EBs can be induced after application of growth factors of the transforming growth factor $\beta$ family (Kramer et al., 2000) we applied BMP-2, TGF- $\beta_{1}$ and TGF$\beta_{3}$ to differentiating Sox9-- EBs. However, we did not detect any cartilage nodule in these EB outgrowths (data not shown) indicating that loss of Sox9 function cannot be rescued by these chondrogenic factors in vitro. In Sox9+/- EB outgrowths, cartilage nodules were present, but the number of nodules appeared to be reduced compared to the wildtype, indicating that Sox 9 gene dosage is important for proper cartilage differentiation. This agrees with the observation that cartilage structures are defective and hypoplastic but not completely absent in CD patients and Sox9+/- mice (Houston et al., 1983; Bi et al., 2001). Taken together, this demonstrates that Sox9 plays an essential role during chondrogenesis both in vivo and in vitro.

It has been proposed that Sox9 plays an inhibitory role for the switch from prehypertrophic to hypertrophic chondrocytes, because Sox9 is completely switched off in hypertrophic chondrocytes in vivo (Zhao et al., 1997; Bi et al., 2001). Furthermore, in prehypertrophic chondrocytes of mice lacking the receptor for the parathyroid hormone-related peptide, Sox9 phosphorylation is abolished and these mice show accelerated differentiation of hypertrophic chondrocytes (Lanske et al., 1996; Huang et al., 2001). Our data suggest that Col10a 1expression and the number

Fig. 6. Loss of Sox9 function does not affect the formation of precartilage condensations in vitro. In situ hybridization using an antisense probe detecting scleraxis $\operatorname{mRNA}(\mathbf{A}, \mathbf{B}, \mathbf{C})$ combined with immunostaining for $\mathrm{N}$-Cadherin $(\mathbf{D}, \mathbf{E}, \mathbf{F})$ and $D / C$ microscopy $(\mathbf{G}, \mathbf{H}, \mathbf{I})$ showed that mesenchymal cells in wildtype (wt; $A, D, G$ ), Sox9+/-D4D6 $(B, E, H)$ and Sox9-/- D4D12-C4 (C,F,I) EBs form condensations $(\mathbf{G}, \mathbf{H}, \mathbf{I})$ which express scleraxis $(\mathbf{A}, \mathbf{B}, \mathbf{C})$ and $\mathrm{N}$-Cadherin $(\mathbf{D}, \mathbf{E}, \mathbf{F})$. Representative areas from EB outgrowths are shown. DIC, differential interference contrast. Scale bar, $100 \mu \mathrm{m}$. Scleraxis-positive pre-cartilage condensations were found in EB outgrowths of the three ES cell clones during in vitro differentiation from 5 days $(5+5$ d) up to 31 days $(5+31$ d) after $E B$ plating $(\mathbf{J})$. Data are shown for wildtype, the heterozygous clone D4D6 and the homozygous clone D4D12-C4. The number of scleraxis-positive condensations did not differ significantly between EBs of the three genotypes. Mean values from at least three independent experiments are shown. Approximately 50 EBs were analyzed per time point. 
of Col10a1-expressing cells increase in Sox9+/-nodules. These results indicate that a reduced level of Sox9 may promote the formation of hypertrophic chondrocytes. In line with this, Sox9+/mice showed an enlarged zone of chondrocyte hypertrophy in the growth plates of the long bones (Bi et al., 2001).

\section{Formation of pre-cartilage condensations is not affected in Sox9-/- EBs}

We found that during ES cell differentiation in vitro, Sox9deficient cells form early pre-cartilage condensations which express Sox5, Sox6, scleraxis and $\mathrm{N}$-cadherin, markers characteristic for such pre-cartilage condensations (Oberlender and Tuan, 1994; Lefebvre et al., 1998; Brown et al., 1999). Furthermore, the condensations strongly bind the lectin PNA (DeLise et al., 2000). These results were not only obtained with both subclones from the Sox9-/- clone D4D12, lacking exon 2, but also with the independent Sox9-/- clone 2A5-40, lacking exons 2 plus 3.

In mouse chimeras, Sox9-/- cells were located adjacent to condensing wildtype mesenchymal cells in 11.5 and 12.5 d p.c. embryos and did not take part in the formation of mesenchymal condensations (Bi et al., 1999). Moreover, conditional null mutant mice, in which Sox9was inactivated in mesenchymal cells of limb buds before these cells condense, were no longer able to form mesenchymal condensations (Akiyama et al., 2002). These results suggested that condensation formation is a cell-autonomous process under the control of Sox9. On the other hand, zebrafish with homozygous null mutations in the sox9agene, an ortholog of the mammalian Sox9gene, are able to form mesenchymal condensations in the first two pharyngeal arches (Yan et al., 2002). We have shown in the present study, that a homogeneous population of Sox9-deficient cells is able to form precartilage condensations and express early molecular markers in vitro. Thus, our data indicate that the function of Sox9 during condensation formation is rather not cell-autonomous.

In vivo, development is not only temporally controlled as in EBs, but is also spatially controlled by a combination of distinct signaling molecules present at defined concentrations. Because morphogenetic development is not possible within EBs, such spatially controlled signals might be lacking, resulting in condensation of mesenchymal cells in Sox9/- EBs. In line with this, a variability of morphogenetic signals around pre-cartilage condensations in EB outgrowths might influence their cellular fate. In fact, we found that in wildtype EBs only some of the condensations develop into cartilage nodules, and the mean number of scleraxis-positive condensations does not decrease significantly during culture. Thus, the in vitro system offers the possibilty to analyze the potency of cell-autonomous differentiation effects. The formation of specifically shaped mesenchymal condensations in vivomay be regulated by antagonistic factors produced by ectodermal or non-condensing mesenchymal cells located close to the place of the condensations (Zanetti and Solursh, 1986). For example, in limb buds, the size and shape of mesenchymal condensations is controlled by inhibitory factors produced by ectodermal cells such as FGF2 and FGF8 (Moftah et al., 2002). Sox 9 could be an antagonist of such condensation-inhibiting factors, which are expressed in vivo by the overlaying ectoderm. The absence of Sox9 would then result in the complete loss of condensations in vivo. In contrast, in the $E B$ in vitrodifferentiation system, the release of such condensation-inhibiting factors from

adjacent tissue can not occur and therefore condensations can form even in the absence of Sox9. Similarly, it has been found that scleraxis null mutant embryos fail to form mesoderm, whereas in EBs of scleraxis-/- ES cells, mesodermal markers were expressed at a similar level as in wildtype EBs (Brown et al., 1999) indicating that the role of scleraxis during mesoderm formation is not cell-autonomous but depends on the environment. Another example are mice lacking a transcription factor, the serum response factor (Srf). These Srf-/- mice stop developing at the onset of gastrulation and do not form mesoderm (Arsenian et al., 1998). However, Srf-/- ES cells differentiated in vitro into mesodermal cell types although this process was impaired in vivo(Weinhold et al., 2000) suggesting that the function of Srf to promote mesoderm formation is non-cell-autonomous. Our data indicate that a non cell-autonomous function may also apply to Sox9 regarding the formation of pre-cartilage condensations.

\section{Loss of Sox9 affects the level of but does not completely abolish Col2a1 expression in vitro}

Expression studies in vivosuggested that Col2a 1 is a target for Sox9, because Sox9 and Col2a1 are coexpressed in cartilage primordia throughout the developing skeleton and in other developing cartilage structures during embryogenesis (Zhao et al., 1997; $\mathrm{Ng}$ et al., 1997). It has also been shown that Sox9 binds to

A
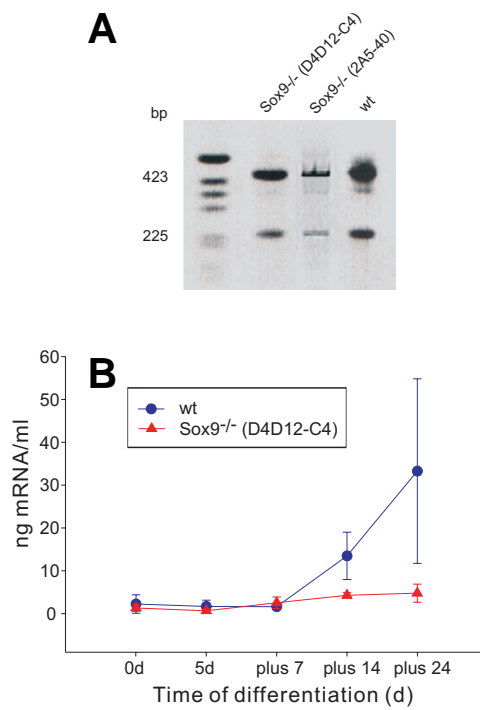

Fig. 7. Expression of Col2a 1 is clearly downregulated, but not completely abolished, during in vitro differentiation of Sox9-deficient ES cells. Both the adult (225 bp) and the juvenile (432 bp) splice variants of Col2a1 were expressed in the absence of Sox9 as analyzed by conventional RT-PCR in 5+22 d EBs derived from wildtype (wt) and Sox9-deficient clones D4D12-C4 and 2A5-40 (A). However, the level of gene expression of Col2a1 as analyzed by real time RT-PCR during differentiation of wildtype (wt) and Sox9-- ES cells (clones D4D12-C4 and 2A5-40) was clearly reduced in Sox9-/- EBs compared to wildtype EBs (B). Data are shown for clone D4D12-C4. RNA isolated from undifferentiated ES cells (Od) and EBs at $5 d, 5+7 d, 5+14 d$ and $5+24$ was analyzed. Immunostainings showed that collagen II fibres were scattered throughout EBs derived from wildtype (C) and Sox9-/-ES cells (D) at 5+28d. Collagen type /l fibre formation is independent of cartilage nodule formation which is missing in the absence of Sox9. Scale bar, $100 \mu \mathrm{m}$. 
specific sequence elements of the Col2a1 enhancer and directs chondrocyte-specific Col2a 1 expression, both in transient transfection experiments and in transgenic mice (Lefebvre et al., 1996; Bell et al., 1997; Lefebvre etal., 1997; Zhou etal., 1998). In mouse chimeras, Sox9-1- cells did not express Col2a1, and in Sox9-/teratomas, type II collagen was not detectable in any cell type (Bi et al., 1999). In contrast, coexpression studies of Sox9 and Col2a1 in developing wild type mouse embryos revealed that Col2a1 was expressed in several nonskeletal tissues which are negative for Sox9( $\mathrm{Ng}$ et al., 1997), indicating that differentiating cells are able to express Col2a 1 in the absence of Sox9. Furthermore, type II collagen expression in cultured human articular chondrocytes does not correlate with the level of Sox9 expression (Aigner et al., 2003). We found that Sox9-deficiency did not result in complete abolishment but obvious downregulation of Col2a1 expression in differentiating EBs, as shown by real-time RT-PCR and by detection of type II collagen fibres in Sox9-/- EB outgrowths. One possible explanation for this unexpected result could be that we generated a partially functional Sox9 protein by our gene targeting strategy. This can be ruled out, as we did not detect any Sox9 protein in cultured Sox9-- EBs. Furthermore, it has been shown recently that no functional Sox9 protein could be detected after conditional inactivation of Sox9in the lung using the same targeting strategy resulting in Sox9-depx2,3 alleles (Perl et al., 2005). Moreover, even if a truncated protein was still produced in the knock-out lines this mutant Sox9 protein would lack a functional DNA binding domain and the C-terminal transactivation domain (Südbeck et al., 1996) and would thus not be able to function as a transcription factor.

Another explanation would be compensation of Sox9function in vitroby a protein with an overlapping function. The transcription factors Sox5 and Sox6 would be candidates. Both were expressed in Sox9-deficient condensations in vitro and might upregulate Col2a1 expression at least to moderate expression levels. Such a compensatory mechanism may depend on the prior formation of mesenchymal condensations. This agrees with the observation that in conditional null mutant mice, expression of Col2a1 as well as Sox5and Sox6 was inhibited when Sox9 was inactivated in mesenchymal cells before condensations had been formed (Akiyama et al., 2002).

In conclusion, this in vitro study unravels a mechanistic insight into the function of Sox9 during chondrogenic differentiation. We found that in contrast to the terminal step of differentiation characterized by the formation of cartilage nodules, the early step of pre-chondrogenic differentiation, the formation of pre-cartilage condensations, remained almost unaffected after loss of Sox9 function in vitro. In contrast, a block of this early differentiation step has previously been demonstrated in vivo. This indicates that the function of Sox9 during this process is not cell-autonomous. Thus, the in vitrodifferentiation of embryonic stem cells is a useful approach to bring new important insights into complex developmental processes.

\section{Materials and Methods}

\section{Generation of Sox9+/- and Sox9-/- ES cells}

Gene targeting of Sox9 was achieved by electroporation of E14.1 ES cells (Kuhn et al., 1991) with a targeting vector containing a loxP-flanked MC1-neo-pA cassette inserted into intron 1, a third loxP site inserted into intron 2, and a PGK-tk-pA negative selection cassette (Kist et al., unpublished data) generating the Sox9-neoflox2 allele. The targeting vector is thus largely identical to the targeting vector described previously which resulted in the Sox9-neofloxallele (Kist et al., 2002), except that the third loxP site is placed within intron 2 instead of downstream of exon 3. Cultivation, electroporation and drug selection of E14.1 ES cells was according to standard procedures (Matise et al., 2000). Correctly targeted ES cell clones were identified and confirmed by Southern blot analysis using specific hybridisation probes (Kist et al., unpublished). In order to generate Sox9+/- ES cell clones by transient in vitro expression of Cre recombinase, correctly targeted Sox9ES cell clones were electroporated with $p C r e-P a c$ expression vector and selected with puromycin as described (Taniguchi et al., 1998). Fortuitously, a Sox9-/- ES cell clone, termed D4D12, was obtained in which the wildtype allele on the nontargeted chromosome had been replaced by the mutant allele lacking exon 2. The underlaying mechanisms of such chromosome-specific loss of heterozygosity has been discussed elsewhere (Lefebvre et al., 2001).

A different Sox9-- ES cell line was generated from a clone, termed 2A, carrying the Sox9-neoflox allele in a heterozygous configuration (Kist et al., 2002). After drug selection with high concentrations of G418 of 10 and $12 \mathrm{mg} / \mathrm{ml}$ for 38 days, surviving clones were picked, genomic DNA was isolated and screened by PCR for homozygosity of the Sox9-neoflox allele. A clone, termed 2A5, was obtained which carried two Sox9-neoflox alleles. This clone was transfected with the $p$ Cre-Pacexpression vector and cells were selected with puromycin as described above.

For subcloning, Sox9-/- ES cell clones D4D12 and 2A5 were plated at low density and new subclones, termed D4D12-C4, D4D12-D6 and 2A540 , were isolated and confirmed by Southern Blotting.

\section{Cell culture and differentiation of EBs}

Differentiation of chondrogenic cells in vitrowas studied during differentiation of the Sox9+/- ES cell clone D4D6 and the Sox9-/- ES cell clones D4D12-C4 and D4D12-D6, lacking exon 2, and 2A5-40, lacking exon 2 and exon 3, in comparison to the wildtype ES cell line E14.1. ES cells were grown on a feeder layer of mitomycin C-inactivated mouse embryonic fibroblasts in cultivation medium consisting of DME (INVITROGEN, Karlsruhe, FRG) supplemented with 15\% FCS (INVITROGEN, Karlsruhe, FRG), non-essential amino acids (INVITROGEN, Karlsruhe, FRG, stock solution diluted 1:100), $2 \mathrm{mM}$ L-glutamine (INVITROGEN, Karlsruhe, FRG) and 5x10-5 M $\beta$-mercaptoethanol (SERVA, Heidelberg, FRG), as described previously for line D3 (Kramer et al., 2000). For differentiation, aliquots of $20 \mu \mathrm{l}$ differentiation medium (containing 20\% FCS instead of $15 \%$ ) containing 800 cells were cultivated in «hanging drops» for 2 days and, after transfer on bacteriological petri dishes, in suspension for an additional 3 days (Kramer et al., 2000). The 5 day ( $" 5 \mathrm{~d} »)$ old EBs were plated separately onto gelatin $(0.1 \%)$-coated 24 well microwell plates for morphological analysis, or $15 \mathrm{EBs}$ were plated onto a $6 \mathrm{~cm}$ tissue culture plate for Alcian blue staining and RT-PCR, or 10 EBs onto 2 well $(21,3 \mathrm{x}$ $20 \mathrm{~mm}$ ) Lab-Tek chamber slides (NUNC, Wiesbaden, FRG) for immunostaining, in situhybridization and test for PNA binding. Alcian blue stainings were performed as described previously (Kramer et al., 2000). We performed at least three differentiation experiments per cell line and analyzed approximately 200 EBs per time point by Alcian blue staining. Data analysis was performed using the Sigma Plot 5.0 software (JANDEL, Corte Madeira, USA). The Student's t-test was used for statistical analysis.

\section{Quantitatitve measurement of Col2a1 gene expression by real-time- $R T$-PCR analysis}

Samples of ten EBs of different developmental stages up to 26 days after plating $(5+26 \mathrm{~d})$ were collected, washed two times with PBS, and total RNA was isolated and reverse transcribed as described (Hegert et al., 2002). Aliquots of $1 \mu \mathrm{l}$ from the RT reactions were mixed with $10 \mathrm{pmol}$ primer specific for Col2a1 (sense: $5^{\prime}$-TTTCCTCCGTCTACTGTCCACTG3'-; antisense: 5'-TGTATGTGAACCTGCTGTTGC $\neq$ C-3'; product size:161 bp) and real-time PCR was carried out with the $\mathrm{IQ}$ SYBR Green 
Supermix (BIORAD, Munich, FRG) using an iCyler iQ thermal cycler (BIORAD, Munich, FRG) according to the manufacturer's instructions. The thermal cycling conditions were $95^{\circ} \mathrm{C}$ for 2 minutes followed by 40 cycles of $95^{\circ} \mathrm{C}$ for 40 seconds, $58^{\circ} \mathrm{C}$ for 40 seconds and $72{ }^{\circ} \mathrm{C}$ for 40 seconds. To confirm the specificity of the amplified products, melting curves were performed at the end of the amplification by cooling samples to $58{ }^{\circ} \mathrm{C}$ for 1 minute and then increasing temperature to 95 ${ }^{\circ} \mathrm{C}$ at $0.05{ }^{\circ} \mathrm{C} /$ second with continuous fluorescence measurement. Each sample was tested in duplicate. For generation of standard curves, the PCR product was cloned into the vector pCR-TOPO (INVITROGEN, Karlsruhe, FRG). Plasmid DNA was isolated using QIAGEN-tip 100 anion-exchange columns (QIAGEN) and serially diluted in double-distilled water. Threshold cycles are adjusted to attain the highest possible correlation coefficient value for the standard curve provided by the manufacturer's software. According to their respective cycle numbers the concentrations of unknown samples were deduced from the standard curve.

\section{Conventional RT-PCR analysis}

RT-PCR reactions were carried out with sequence-specific primers as described previously (Kramer et al., 2000; Hegert et al., 2002). To study expression of Col2a1 and Sox9, respectively, the following primers were used (oligonucleotide sequences are given in brackets in the order antisense-, sense-primer followed by the annealing temperature used for PCR, length of the amplified fragment and a reference): Col2a1 5' - AGGGGTACCAGGTTCTCCATC - 3',

5' - CTGCTCATCGCCGCGGTCCTA - 3'; 60 $\mathrm{C} ; 432 \mathrm{bp}$ (splice variant A) and 225 bp (splice variant B); (Metsäranta et al., 1991);

Sox9 5' - TGGGTGGCAAGTATTGGTCAAACTCA -3', 5' - TGAAGAAGGAGAGCGAGGAAGATAA 3'; 57 $\mathrm{C} ; 23$ bp; (Lefebvre et al., 1998). Electrophoretic separation of PCR products was carried out on $2 \%$ agarose gels.

\section{Cloning of PCR fragments for sequence analysis}

Reverse Transcription was performed as described above. cDNA was amplified by PCR using Vent-DNA-polymerase (NEW ENGLAND BIOLABS, Frankfurt, FRG). 723 bp and 469 bp long Sox 9 cDNA fragments amplified from RNA isolated from wildtype and Sox9/(clone D4D12-C4) cells, respectively, were excised from a 2\% agarose gel after electrophoretic separation, and purified using the QIAquick Gel Extraction Kit (QIAGEN, Hilden, FRG). These fragments were cloned blunt-ended into the plasmid vector $\mathrm{PCR} \otimes$-Blunt using the Zero Blunt ${ }^{\mathrm{TM}}$ PCR Cloning Kit according to the manufacturer's protocol (INVITROGEN, Karlsruhe, FRG). Clones carrying inserts of the expected length were selected after restriction enzyme digestion and their nucleotide sequence was verified by sequencing (MWG-Biotech, Ebersberg, FRG).

\section{Fluorescence in situ hybridisation coupled with immunostaining}

The combination of fluorescence in situ hybridization and immunostaining as well as cloning of the scleraxis and Col10a1cDNAs used to generate RNA probes by in vitro transcription have been described previously (Kramer et al., 2000). The probes used to detect Sox5and Sox6have been described elsewhere (Lefebvre et al., 1998). Ten EBs were plated per chamber slide and analyzed at different developmental stages. The monoclonal antibody II-II6B3 (Developmental Studies Hybridoma Bank, University of lowa, USA) against type II collagen or the monoclonal anti-A-CAM antibody GC-4 (SIGMA, Taufkirchen, FRG) to detect $\mathrm{N}$-Cadherin was applied in a 1:20 or 1:40 dilution, respectively. For immunostaining against Sox9 we used a polyclonal antibody from Santa Cruz (Heidelberg, FRG) diluted 1:200. Secondary antibodies were 1:100 diluted FITC-conjugated sheep $F(a b)$ fragments against digoxigenin (BOEHRINGER, Mannheim, FRG) and Cy3- or FITC-conjugated goat anti-mouse or anti-rabbit secondary antibodies (DIANOVA, Hamburg, FRG) diluted 1:800 in PBS. Control slides were hybridized with the respective sense probes and the secondary antibody alone.

\section{PNA binding}

To test for binding of Peanut agglutinin (PNA) to pre-cartilage condensations, EBs plated onto chamber slides were washed three times with PBS, fixed in $3.7 \%$ formaldehyde in PBS for 30 minutes at room temperature and washed again three times with PBS. FITClabeled PNA (BIOMEDA, Foster City, USA) was applied at a concentration of $0.1 \mathrm{mg} / \mathrm{ml}$ and incubated for 45 minutes at room temperature. After washing four times in PBS, specimen were embedded in Vectashield mounting medium (VECTOR, Burlinggame, USA).

\section{Acquisition and processing of images}

Slides were analyzed with the fluorescence microscope AXIOSKOP (ZEISS, Oberkochen, FRG) equipped with a 3 CCD color video camera (SONY, Cologne, Germany) using the acquisition software AXIOVISION (ZEISS, Oberkochen, FRG). Figures were assembled using the COREL DRAW software (COREL Corp., Ottawa, Canada).

\section{Acknowledgements}

The skilful technical assistance of $A$. Eirich and M. Dose and is gratefully acknowledged. The II-I/6B3 monoclonalantibody developed by T. F. Linsenmayer was obtained from the Developmental Studies Hybridoma Bank developed under the auspices of the NICHD and maintained by the University of lowa, Dept. of Biological Sciences, lowa City, IA52242. The work was supported by grants from the Deutsche Forschungsgemeinschaft to J.R. (Ro 2108/1-1 and 1-2) and to G.S. (Sche 194/11-3) and by funding from Intermed Service GmbH, Geesthacht. The probes used for Sox5 and Sox6 mRNA in situ hybridization were kindly provided by V. Lefebvre (Cleveland Clinic Foundation, Cleveland, $\mathrm{OH}$, U.S.A.).

\section{References}

AIGNER, T., GEBHARD, P.M., SCHMID, E., BAU, B., HARLEY, V. and POSCHL, E. (2003). SOX9 expression does not correlate with type II collagen expression in adult articular chondrocytes. Matrix Biol. 22: 363-372.

AKIYAMA, H., CHABOISSIER, M.C., MARTIN, J.F., SCHEDL, A. and DE CROMBRUGGHE, B. (2002). The transcription factor Sox9 has essential roles in successive steps of the chondrocyte differentiation pathway and is required for expression of Sox5 and Sox6. Genes Dev. 16: 2813-2828.

ARSENIAN, S., WEINHOLD, B., OELGESCHLAGER, M., RUTHER, U. and NORDHEIM, A. (1998). Serum response factor is essential for mesoderm formation during mouse embryogenesis. EMBO J. 17: 6289-6299.

BELL, D.M., LEUNG, K.K., WHEATLEY, S.C., NG, L.J., ZHOU, S., LING, K.W., SHAM, M.H., KOOPMAN, P., TAM, P.P. and CHEAH, K.S. (1997). SOX9 directly regulates the type-Il collagen gene. Nat. Genet. 16: 174-178.

BI, W., DENG, J.M., ZHANG, Z., BEHRINGER, R.R. and DE CROMBRUGGHE, B. (1999). Sox9 is required for cartilage formation. Nat. Genet. 22: 85-89.

BI, W., HUANG, W., WHITWORTH, D.J., DENG, J.M., ZHANG, Z., BEHRINGER, R.R. and DE CROMBRUGGHE, B. (2001). Haploinsufficiency of Sox9 results in defective cartilage primordia and premature skeletal mineralization. Proc. Natl. Acad. Sci. U. S. A 98: 6698-6703.

BOWLES, J., SCHEPERS, G. and KOOPMAN, P. (2000). Phylogeny of the SOX family of developmental transcription factors based on sequence and structural indicators. Dev. Biol. 227: 239-255.

BRIDGEWATER, L.C., LEFEBVRE, V. and DE CROMBRUGGHE, B. (1998). Chondrocyte-specific enhancer elements in the Col11a2 gene resemble the Col2a1 tissue-specific enhancer. J. Biol. Chem. 273: 14998-15006.

BROWN, D., WAGNER, D., LI, X., RICHARDSON, J.A. and OLSON, E.N. (1999). Dual role of the basic helix-loop-helix transcription factor scleraxis in mesoderm formation and chondrogenesis during mouse embryogenesis. Development 126: 4317-4329.

CSERJESI, P., BROWN, D., LIGON, K.L., LYONS, G.E., COPELAND, N.G., 
GILBERT, D.J., JENKINS, N.A. and OLSON, E.N. (1995). Scleraxis: a basic helix-loop-helix protein that prefigures skeletal formation during mouse embryogenesis. Development 121: 1099-1110.

DE CROMBRUGGHE, B., LEFEBVRE, V. and NAKASHIMA, K. (2001). Regulatory mechanisms in the pathways of cartilage and bone formation. Curr. Opin. Cell Biol. 13: 721-727.

DELISE, A.M., FISCHER, L. and TUAN, R.S. (2000). Cellular interactions and signaling in cartilage development. Osteoarthritis. Cartilage. 8: 309-334.

FOSTER, J.W., DOMINGUEZ-STEGLICH, M.A., GUIOLI, S., KOWK, G., WELLER, P.A., STEVANOVIC, M., WEISSENBACH, J., MANSOUR, S., YOUNG, I.D., GOODFELLOW, P.N. and SCHAFER, A.J. (1994). Campomelic dysplasia and autosomal sex reversal caused by mutations in an SRY-related gene. Nature 372: 525-530.

HEGERT, C., KRAMER, J., HARGUS, G., MÜLLER, J., GUAN, K., WOBUS, A.M., MÜLLER, P.K. and ROHWEDEL, J. (2002). Differentiation plasticity of chondrocytes derived from mouse embryonic stem cells. J. Cel/ Sci. 115: 46174628.

HOUSTON, C.S., OPITZ, J.M., SPRANGER, J.W., MACPHERSON, R.I., REED, M.H., GILBERT, E.F., HERRMANN, J. and SCHINZEL, A. (1983). The campomelic syndrome: review, report of 17 cases, and follow-up on the currently 17-year-old boy first reported by Maroteaux et al. in 1971. Am. J. Med. Genet. 15: 3-28.

HUANG, W., CHUNG, U.I., KRONENBERG, H.M. and DE CROMBRUGGHE, B. (2001). The chondrogenic transcription factor Sox9 is a target of signaling by the parathyroid hormone-related peptide in the growth plate of endochondral bones. Proc. Natl. Acad. Sci. USA 98: 160-165.

KIST, R., SCHREWE, H., BALLING, R. and SCHERER, G. (2002). Conditional inactivation of Sox9: a mouse model for campomelic dysplasia. Genesis. 32: 121-123.

KRAMER, J., HEGERT, C., GUAN, K., WOBUS, A.M., MÜLleR, P.K. and ROHWEDEL, J. (2000). Embryonic stem cell-derived chondrogenic differentiation in vitro: activation by BMP-2 and BMP-4. Mech. Dev. 92: 193-205.

KRAMER, J., KLINGER, M., KRUSE, C., FAZA, M., HARGUS, G. and ROHWEDEL, J. (2005). Ultrastructural analysis of mouse embryonic stem cell-derived chondrocytes. Anat. Embryol. (Berl). 210: 175-185.

KUHN, R., RAJEWSKY, K. and MÜLLER, W. (1991). Generation and analysis of interleukin-4 deficient mice. Science 254: 707-710.

LANSKE, B., KARAPLIS, A.C., LEE, K., LUZ, A., VORTKAMP, A., PIRRO, A., KARPERIEN, M., DEFIZE, L.H., HO, C., MULLIGAN, R.C., ABOU-SAMRA, A.B., JUPPNER, H., SEGRE, G.V. and KRONENBERG, H.M. (1996). PTH/ PTHrP receptor in early development and Indian hedgehog-regulated bone growth. Science 273: 663-666.

LEFEBVRE, L., DIONNE, N., KARASKOVA, J., SQUIRE, J.A. and NAGY, A. (2001). Selection for transgene homozygosity in embryonic stem cells results in extensive loss of heterozygosity. Nat. Genet. 27: 257-258.

LEFEBVRE, V., HUANG, W., HARLEY, V.R., GOODFELLOW, P.N. and DE CROMBRUGGHE, B. (1997). SOX9 is a potent activator of the chondrocytespecific enhancer of the pro alpha1 (II) collagen gene. Mol. Cell Biol. 17: 23362346.

LEFEBVRE, V., LI, P. and DE CROMBRUGGHE, B. (1998). A new long form of Sox5 (L-Sox5), Sox6 and Sox9 are coexpressed in chondrogenesis and cooperatively activate the type II collagen gene. EMBO J. 17: 5718-5733.

LEFEBVRE, V., ZHOU, G., MUKHOPADHYAY, K., SMITH, C.N., ZHANG, Z., EBERSPAECHER, H., ZHOU, X., SINHA, S., MAITY, S.N. and DE CROMBRUGGHE, B. (1996). An 18-base-pair sequence in the mouse proalpha1(II) collagen gene is sufficient for expression in cartilage and binds nuclear proteins that are selectively expressed in chondrocytes. Mol. Cell Biol. 16: 4512-4523.

MANSOUR, S., HALL, C.M., PEMBREY, M.E. and YOUNG, I.D. (1995). A clinical and genetic study of campomelic dysplasia. J. Med. Genet. 32: 415-420.

MATISE, M. P., AUERBACH, W., and JOYNER, A. L. 2000. Production of Targeted Embryonic Stem Cell Clones. In Gene Targeting: A PracticalApproach(JOYNER,
A. L., ed.). Oxford University Press, Oxford, pp.101-132.

METSÄRANTA, M., TOMAN, D., DE CROMBRUGGHE, B. and VUORIO, E. (1991). Mouse type II collagen gene. Complete nucleotide sequence, exon structure, and alternative splicing. J. Biol. Chem. 266: 16862-16869.

MOFTAH, M.Z., DOWNIE, S.A., BRONSTEIN, N.B., MEZENTSEVA, N., PU, J., MAHER, P.A. and NEWMAN, S.A. (2002). Ectodermal FGFs induce perinodular inhibition of limb chondrogenesis in vitro and in vivo via FGF receptor 2. Dev. Biol. 249: 270-282.

MORTENSEN, R.M., CONNER, D.A., CHAO, S., GEISTERFER-LOWRANCE, A.A. and SEIDMAN, J.G. (1992). Production of homozygous mutant ES cells with a single targeting construct. Mol. Cell Biol. 12: 2391-2395.

NG, L.J., WHEATLEY, S., MUSCAT, G.E., CONWAY-CAMPBELL, J., BOWLES, J., WRIGHT, E., BELL, D.M., TAM, P.P., CHEAH, K.S. and KOOPMAN, P. (1997). SOX9 binds DNA, activates transcription, and coexpresses with type II collagen during chondrogenesis in the mouse. Dev. Biol. 183: 108-121.

OBERLENDER, S.A. and TUAN, R.S. (1994). Expression and functional involvement of N-cadherin in embryonic limb chondrogenesis. Development 120: 177187.

PERL, A.K., KIST, R., SHAN, Z., SCHERER, G. and WHITSETT, J.A. (2005). Normal lung development and function after Sox 9 inactivation in the respiratory epithelium. Genesis. 41: 23-32.

SEKIYA, I., TSUJI, K., KOOPMAN, P., WATANABE, H., YAMADA, Y., SHINOMIYA, K., NIFUJI, A. and NODA, M. (2000). SOX9 enhances aggrecan gene promoter/ enhancer activity and is up- regulated by retinoic acid in a cartilage-derived cell line, TC6. J. Biol. Chem. 275: 10738-10744.

SÜDBECK, P., SCHMITZ, M.L., BAEUERLE, P.A. and SCHERER, G. (1996). Sex reversal by loss of the $\mathrm{C}$-terminal transactivation domain of human SOX9. Nat. Genet. 13: 230-232.

TANIGUCHI, M., SANBO, M., WATANABE, S., NARUSE, I., MISHINA, M. and YAGI, T. (1998). Efficient production of Cre-mediated site-directed recombinants through the utilization of the puromycin resistance gene, pac: a transient gene-integration marker for ES cells. Nucleic Acids Res. 26: 679-680.

WAGNER, T., WIRTH, J., MEYER, J., ZABEL, B., HELD, M., ZIMMER, J., PASANTES, J., BRICARELLI, F.D., KEUTEL, J., HUSTERT, E., WOLF, U., TOMMERUP, N., SCHEMPP, W. and SCHERER, G. (1994). Autosomal sex reversal and campomelic dysplasia are caused by mutations in and around the SRY-related gene SOX9. Cel/79: 1111-1120.

WEGNER, M. (1999). From head to toes: the multiple facets of Sox proteins. Nucleic Acids Res. 27: 1409-1420.

WEINHOLD, B., SCHRATT, G., ARSENIAN, S., BERGER, J., KAMINO, K., SCHWARZ, H., RUTHER, U. and NORDHEIM, A. (2000). Srf(-/-) ES cells display non-cell-autonomous impairment in mesodermal differentiation. EMBO J. 19: 5835-5844.

WRIGHT, E., HARGRAVE, M.R., CHRISTIANSEN, J., COOPER, L., KUN, J., EVANS, T., GANGADHARAN, U., GREENFIELD, A. and KOOPMAN, P. (1995). The Sry-related gene Sox9 is expressed during chondrogenesis in mouse embryos. Nat. Genet. 9: 15-20.

YAN, Y.L., MILLER, C.T., NISSEN, R.M., SINGER, A., LIU, D., KIRN, A., DRAPER, B., WILlOUGHBY, J., MORCOS, P.A., AMSTERdAM, A., CHUNG, B.C., WESTERFIELD, M., HAFFTER, P., HOPKINS, N., KIMMEL, C., POSTLETHWAIT, J.H. and NISSEN, R. (2002). A zebrafish sox9 gene required for cartilage morphogenesis. Development 129: 5065-5079.

ZANETTI, N.C. and SOLURSH, M. (1986). Epithelial effects on limb chondrogenesis involve extracellular matrix and cell shape. Dev. Biol. 113: 110-118.

ZHAO, Q., EBERSPAECHER, H., LEFEBVRE, V. and DE CROMBRUGGHE, B. (1997). Parallel expression of Sox9 and Col2a1 in cells undergoing chondrogenesis. Dev. Dyn. 209: 377-386.

ZHOU, G., LefEBVRE, V., ZHANG, Z., EBERSPAECHER, H. and DE CROMBRUGGHE, B. (1998). Three high mobility group-like sequences within a 48-base pair enhancer of the Col2a1 gene are required for cartilage-specific expression in vivo. J. Biol. Chem. 273: 14989-14997. 


\section{Related, previously published Int. J. Dev. Biol. articles}

See our Special Issue Ear Development edited by Fernando Giraldez and Bernd Fritzsch at: http://www.ijdb.ehu.es/web/contents.php?vol=51\&issue=6-7

Expression of $\mathrm{N}$-cadherin, N-CAM, fibronectin and tenascin is stimulated by TGF-beta1, beta2, beta3 and beta5 during the formation of precartilage condensations.

$\mathrm{J}$ Chimal-Monroy and L Díaz de León

Int. J. Dev. Biol. (1999) 43: 59-67

Immunodetection of the transforming growth factors beta $\mathbf{1}$ and beta $\mathbf{2}$ in the developing murine palate. A L Gehris, M D'Angelo and R M Greene

Int. J. Dev. Biol. (1991) 35: 17-24

A change in response to Bmp signalling precedes ectodermal fate choice

Chris T. Dee, Abigail Gibson, Andrea Rengifo, Shun-Kuo Sun, Roger K. Patient and Paul J. Scotting

Int. J. Dev. Biol. (2007) 51: 79-84

BMP2/4 and BMP5-8 in jellyfish development and transdifferentiation

Susanne Reber-Müller, Ruth Streitwolf-Engel, Nathalie Yanze, Volker Schmid, Michael Stierwald, Michael Erb and Katja Seipel Int. J. Dev. Biol. (2006) 50: 377-384

Selection and amplification of a bone marrow cell population and its induction to the chondro-osteogenic lineage by rhOP1: an in vitro and in vivo study.

J A Andrades, J A Santamaría, M E Nimni and J Becerra

Int. J. Dev. Biol. (2001) 45: 689-693

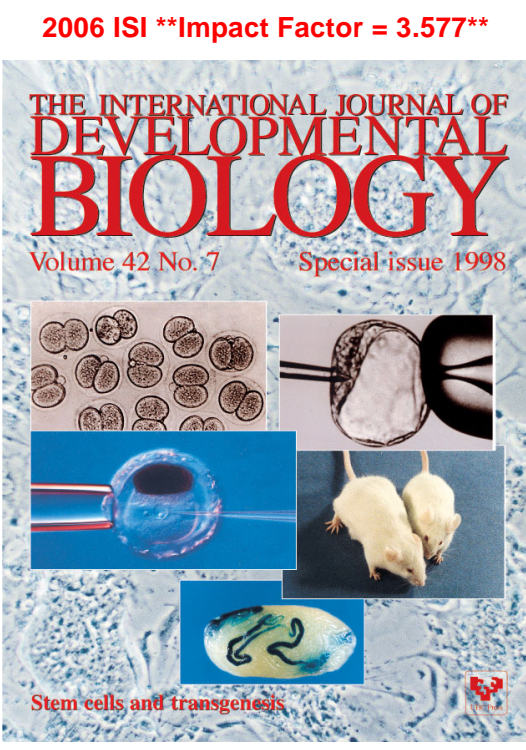

